\title{
The Influence of Principal's Leadership Style, Teacher's Commitment and Work Spirit on Teacher's Performance in Junior High School in Banjarbaru City
}

Juaini *, Aslamiah, Suhaimi

Master Program of Educational Management, Universitas Lambung Mangkurat, Banjarmasin 70123, Indonesia

Article history:

Submission December 2019

Revised April 2020

Accepted May 2020

*Corresponding author:

E-mail: juaini.spd27@gmail.com

\begin{abstract}
This study aims to describe the influence of the principal's leadership style, teacher's work commitment, teacher's work spirit, towards the teacher's performance of junior high school teachers in Banjarbaru City. The sample is determined through the steps of determining the proportional random sampling technique of each member of the sub-population based on the number of schools studied so that a sample of teachers is obtained to study 225 people. The results showed: There was a significant direct effect on the principal's leadership style, the work commitment of teachers to the work spirit of junior high school teachers in Banjarbaru City. There is a significant direct effect of teacher morale, school principal leadership style, and teacher work commitment on the performance and there is a significant indirect effect of the principal's leadership style and teacher's work commitment through the teacher's work enthusiasm on the performance. The result it is expected that they can understand the types of good leadership, and then can be applied in the school environment to provide examples and support for teachers to have a high spirit or work and work commitment in achieving better performance.
\end{abstract}

Keywords: Leadership, work spirit, performance, teacher

\section{Introduction}

Globalization creates various challenges and new problems that must be answered, solved to utilize globalization for the benefit of life. Globalization itself is a term that emerged around twenty years ago and began to be so popular as s new ideology for the last five or ten years. As term globalization is so easily accepted or known to people around the world (Nurhaidah, 2015). The globalization era provides a large influence on various aspects of human resource development, including education. Indonesia's efforts in preparing quality human resources are comprehensively and competitively developed through the educational learning process. Bafadal (2016) stated that the core business of education in schools was learning because the intelligent, comprehensive, and competitive output is positively virtualized between students. The educational staff, especially teachers, are needed in the implementation of a quality system.

Teacher performance, which is related to professional attitudes and work spirit, is seen and measured from their responsibilities in carrying out tasks. This performance is manifested in the compliance, commitment, and loyalty of teachers to develop students' potentials and the school's organization progress (Priansa \& Karwati, 2017). According to Luthans (2006), there are several factors 
influencing performance, such as compensation, salary, leadership, commitment, work environment or atmosphere, organizational culture, involvement, and discipline.

The principal as the school administrator as illustrated in the school's organizational structure through the decentralization policy of education will position himself as the most influential person in his school environment. The principal's leadership will run well if the principal can influence his subordinates (Rumapea, 2005). This matter means the role of a leader is needed to carry out school activities administratively. Principals as school managers are required to distribute administrative authority following the duties of teachers in coaching students. They also encourage the implementation of duties and responsibilities of teachers to create a dynamic working environment, commitments, and improve their performance.

The principal's leadership in an educational institution determines its success, while its authority in understanding the teacher's condition influences performance.

The performance of an employee arising from the encouragement of work morale. In terms of quality leadership and with power used to encourage and stimulate the performance of subordinates (Hasim, 2019).The principal understanding is leadership usually in the form of providing work spirit to the teacher. According to Mulyasa (2001), their activities as a manager include the management of 1) humans as the main driving factor in school activities, 2) money as capital and 3) method as a tool to direct people and money to achieve effective organizational goals. A leadership style that is oriented towards human resources influences the teacher's work spirit and performance. According to Soekarso and Putong (2015), there are five leadership styles centered on 1) work, 2) employee, 3) equal attention to work and employees, 4) work of employees, and 5) employees rather than their work. Besides, Tempel (1987) stated that the types of leadership styles are: 1) autocracy, 2) democracy, and 3) free control.
Work commitment in an educational institution is a material review in determining the influence on the subordinate performance. This commitment is used to determine the extent to which subordinates maintain their personality towards organizations, especially educational institutions. According to Yusuf and Syarif (2018), organizational commitment is an employee or subordinate loyalty in helping an organization to achieve its goals, without the desire to resign due to various reasons.

Martin and Nicholas, stated that educational institutions have 3 pillars in growing organizational commitment for teachers, namely 1) A sense of belonging; 2) Passionate on the work, and 3) Ownership of the organization (Agustini, 2011). Furthermore, Suriansyah (2014) stated that affective/attitude commitment is the attitude of employees and their relationship, which is following organizational goals and values. Therefore, those with high and effective commitment tend to remain in the organization out of their desire.

It was concluded that the work commitment of teachers is a major concern and considered a determining factor in improving performance, reducing the level of delay effects, and preventing the increase of responsibility. Commitment is also a loyal attitude and teachers' sense of ownership towards their school.

Work spirit is also one of the factors that influences teacher performance because it allows someone to perform their jobs better. Hasibuan (2013) stated that work spirit is the desire and sincerity of someone to conduct their job properly and disciplined to achieve maximum performance. A high work spirit ensures a person experiences increased productivity. It provides teachers with adequate enthusiasm and ability to carry out their duties to achieve organizational goals.

The working spirit of teachers and their function as educators is not fully implemented outside teaching hours. This is because it influences their performance. Besides, it is important to supervise students, because they need learning control on cognitive, 
psychological, and social developments. However, these cannot be solely achieved by relying on teaching hours but need continuous and comprehensive monitoring.

From the opinion above, it is concluded that performance is influenced by leadership style, commitment, and work spirit.

\section{Material and Methods}

A quantitative approach alongside correlational technique was employed in this research. Besides, a descriptive correlational and quantitative approach was used to collect data in the form of numbers and to test certain hypotheses. The random sampling technique was used to determine each member of the sub-population based on the number of schools studied. The objects of this study were the principal's leadership style, teacher commitment, work spirit, and performance. The population of the study was 14 junior high schools in Banjarbaru, with a total of 513 teachers consisting of 464 civil servants and 49 honorary degree holders in 2018/2019. Data were collected through questionnaires and documentation and analyzed using the path analysis via the SPSS 20 program.

\section{Results and Discussion}

This study discussed the condition of four variables, with the principal's leadership style, work spirit, and performance in the high category. The work spirit variable was in the moderate category. The results of hypothesis testing are as follows:

\section{The influence of the principal's leadership style on work spirit of teachers}

The direct influence of the principal's leadership style on the teacher's work spirit generated a t-count of 10.592 (sign. 0.000). The value of $\mathrm{t}$-table with $\mathrm{df}=222$ was 1.971 . Based on the results of the analysis, it was determined that the principal's leadership style had a direct and significant influence on the work spirit of the teacher because the $\mathrm{t}$-count was greater than $\mathrm{t}$-table with a significant value smaller than 0.05 . It means that each institution had a different policy in the application of the most appropriate leadership style for the convenience of employees.
These results were in line with the calculation results, which obtained a significance level of $0.001<0.05$ and a t-count of 3.630 smaller than t-table of 1.6849 . It showed that the leadership style influenced the work spirit of the teacher. The result of the study was in line with Sari's research (2016), which stated that there was a significant relationship between the institutions' Climate and the Work Spirit of Private Vocational School teachers in Padang Panjang City. The leaders are expected to pay attention to the habits carried out by teachers to determine whether it needs improvement. A comparison of the correlation test showed that the rho count was greater than the rho table by $0.264>$ 0.195 , which means that a good organizational climate influenced one's work spirit in carrying out the task.

Another study conducted by Tarlis (2017) through a simple linear regression equation on employee's work spirit, raised the leadership style variable by 1 , while the value of employee's work spirit increased by 0.518 . It described that the leadership style had a positive influence on employee's work spirit. The organization needs to understand that leadership style is one of the factors that influence an employee's work spirit. Therefore, it encourages employees to be more productive and effective in achieving goals.

\section{The Direct influence of commitment on the work spirit of junior high school teachers}

The direct influence of teachers' commitment to work spirit resulted in a t-count of 3.994 (sign. 0,000). The value of $t$-table with df of 222 was 1.971. Based on the analysis results, it was determined that the commitment of teachers had a direct and significant influence on the work spirit. This is because the $\mathrm{t}$-count was greater than $\mathrm{t}$-table, with a significant value smaller than 0.05 . An increase in teacher commitment had a direct impact on increasing work spirit. Therefore, the teacher's commitment needs to be increased to create a proper work spirit. According to Susanti et al. (2018), high work commitment certainly increased the work spirit of lecturers at Muhammadiyah University of West Sumatra. Therefore, work commitment plays an 
important role in shaping lecturers' good or bad work spirit in terms of salary, supervision, opportunities for advancement, experience, and appreciation. Another study by Fatimah (2015) stated that organizational commitment with a t-count of 5.859, a significant level of 0.000 , and a $\mathrm{P}-$ value of $0.000<0.05$, means that it influences the work spirit in the company. When employees have a good individual commitment, they tend to increase work discipline in their daily work.

\section{The Direct influence of Teacher's work spirit on performance}

The direct influence of the work spirit of teachers on performance resulted in a t-count of 2.313 (sign. 0.002), while the value of $t$-table with df at 221 was 1,971. Based on the results of the analysis, it was determined that the work spirit of the teacher had a direct and significant influence on performance. Besides, because the $\mathrm{t}$-count was greater than the t-table, the significant value was smaller than 0.05 . It means that the work spirit of the teacher in carrying out their learning and the administrative task had high performance.

The results of the study by Sumantri (2017) stated that the t-count value for work spirit was -0.847 , with a significance level of 0.399 . This means that the work spirit did not have a significant influence on teacher performance. However, because the work spirit of the teachers in the State Junior High Schools in Balongpanggang was already high, there was no significant influence on their performance.

According to Werang et al. (2019), the teacher's work spirit had a positive and significant influence on the performance of elementary school teachers in the Mindiptana district, Papua, as shown by the value of R2 by 0.210 with a significance value ( $p$-value) of 0.000 . It means that $21 \%$ of 'teacher performance' in elementary schools in the Mindiptana district, Papua, is described by the independent variable of their work spirit, while other variables described the remaining $79 \%$. It means that at every point/unit increase, the independent variable of 'teacher's work spirit tends to have an impact on 0.210 points/unit in the dependent variable of their performance.
Conversely, every decline of one point/unit on the independent variable of the teacher's work spirit has an impact on a decrease of 0.210 points/unit on the dependent variable of their performance.

\section{The Direct influence of Principal's leadership style on performance}

The direct influence of the principal's leadership style on the performance of teachers resulted in a t-count of 5.339 (sign. $0,000)$. The value of $t$-table with $\mathrm{df}$ of 221 was 1.971. Based on the results of the analysis, it was determined that the principal's leadership style had a direct and significant influence on teachers' performance because the t-count was greater than t-table and significantly smaller than 0.05 .

The result of this study is to support the result of Andriani et al. (2018) the transformational leadership has a positive effect on SMK teachers in Palembang city. Which means the transformational leadership is followed by the teacher performance improvement. Significantly effect of the influence of $99.1 \%$, the transformational leadership style that encourages the teacher to have vision, mission, and goals, encourage and motivate the teacher to demonstrate the maximum performance. Then, in line with the results of research in Nigeria by Adeyemi (2010) the correlation shows 0.71 between autocratic leadership style and teachers' performance. The correlation coefficient of 0.52 between democratic leadership style and teacher's performance. The correlation coefficient of 0.16 between laissez-faire leadership style and teachers' performance.

The findings of this study indicating better job performance among teachers in schools having principals using an automatic leadership style than in schools having principals using laissez-faire and democratic leadership style. Laissez-faire leadership style is not a good style of leadership that could enhance better job performance among teachers in Senior Secondary schools in Ondo State.

Another research by Noor et al. (2019) the result of the study indicates a relationship between principals' leadership and teachers' performance of teachers in state junior high 
schools. The result show 0.024 is to accept the hypothesis.

\section{The Direct influence of teacher work commit- ments on teacher's performance}

The direct influence of the teacher's work commitment on performance resulted in a $t$ count of 3.510 (sign. 0.001). The value of $t$-table with $\mathrm{df}$ of 221 was 1.971. Based on the analyzed results, it was determined that the teacher's work commitment had a direct and significant influence on performance, because the t-count was greater than the table, with a significant value smaller than 0.05 . It means that their influence in high work commitment increased performance.

The results of this study were in line with Sukamto and Pardjono's research conducted in 2016, which stated that work commitment has a positive influence of 0.325 and was significant for the performance of teachers in Andalan Junior High School in Sleman. The teacher's commitment to their duties is needed in carrying out their duties. The high commitment leads to high performance.

According to Wahyuni et al. (2014) organizational commitment of a teacher to school closely related to performance. High organizational commitment tends to motivate teachers to maximize their performance. Another similar study conducted by Suriansyah (2014) showed that there was a significant relationship between work commitments to the performance of teachers of State Elementary Schools in Banjarmasin. It means that job involvement was related to organizational commitment in shaping individual behavior, and was a strong predictor. Teachers, less involved in work or not performing optimally, show low organizational commitment.

The Direct influence of influence of principal's leadership style through the teacher's work spirit on performance

Testing the hypothesis of indirect influence was to carry out through path analysis by calculating each coefficient. The F-count value of 16.847 was then compared with the value of F-table (DF $=222$ was 1.645). Therefore, the value of the f-count was greater than the $F$ - table $(16.847>1.645)$. This means that the principal's leadership style indirectly and significantly influenced teachers to work spirit and performance. It means that the appropriate principal's leadership style provides support for teachers in the proper implementation of their work. This, therefore, can also improve teacher performance in learning preparation, implementation, and assessment.

The results of this study were in line with the study conducted by Pradnyana et al. (2016), which stated that the leadership style and work spirit with a significant value of 0.000 $<0.05$ simultaneously influenced the performance of employees in Badung. According to Dewi's research (2016) in Wonosobo, leadership style had a positive and indirect significant influence on employee performance through employee job satisfaction, which was $0.451 \times 0.344=$ 0.155144 . It is concluded that the transformational leadership style is more inclined compared to the developed transactional leadership style, which is a more effective influence on employee performance through job satisfaction. This is line with findings result of research by Damai et al. (2019) there is an indirect relationship between the headmaster's leadership and teacher performance through the achievement motivation of high school teachers in Banjarmasin.

\section{The Direct influence of teacher commitment through work spirit on performance}

The hypothesis of indirect influence was tested to carry out a path analysis by calculating the coefficients of each path. The Fcount value was then compared with the Ftable value ( $\mathrm{DF}=222$ was 1.645$)$. Therefore, the f-count value was greater than the F-table $28.617>1.645$. Therefore, it was stated that the teacher's commitment had an indirect and significant influence through their work spirit. It is also following competence, therefore it can also improve teacher performance, in the preparation, implementation, and assessment of learning. Employee work spirit is a major driving factor in improving teacher performance.

The results of this study were in line with the study conducted by Anuar (2017) based on 
path analysis, motivation, work spirit, and performance with a value of 0.123 . It was concluded that the most efficient path analysis to improve employee performance was motivated by the work spirit as an intervening variable. Another study by Putri (2018) in the health department of Tabanan Regency in Bali, stated that the mediating role of work spirit on the influence of the environment on employee performance was 0.010 and 0.003 greater than 0.05 .

The results of the study were concluded in the following figure 1.

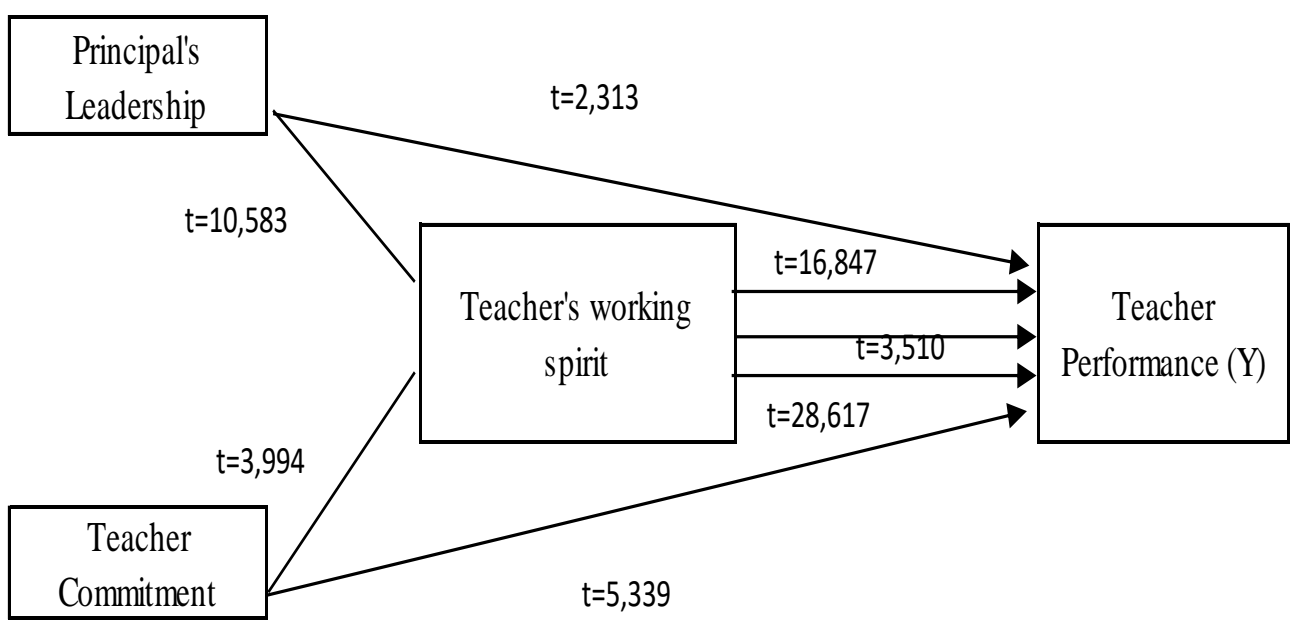

Figure 1. the result of path analysis

\section{Conclusion and Recommendation}

The principal's leadership style, teacher's commitment, and work spirit had a very strong attachment. There was a significant direct influence of the principal's leadership style towards the work spirit of teachers. A direct influence also happens on teacher commitments towards work spirit and performance, as well as the principal's leadership style towards teacher performance. While, indirect influence happens in the principal's leadership style through the teacher's work spirit on performance, also, teacher commitment through work spirit on performance.

It is suggested that principals are expected to understand the types of good leadership skills, and subsequently apply them to the school environment to provide examples and support for teachers to have high work spirit and commitment in achieving better performance. Teachers are expected to improve their performance by understanding the stages of learning preparation, its effectiveness, and efficiency, as well as the implementation process to achieve the vision and mission of the school as an educational institution.

\section{Acknowledgment}

The authors are grateful to the Education Office Banjarbaru city and all teachers of state junior high schools in Banjarbaru City for their assistance and Especially for SMPN 10 Banjarbaru.

\section{References}

Adeyemi, T. (2010). Principals' leadership style and teachers'job performance in senior secondary schools in Ondo State, Nigeria. Journal of Education Administration and Policy Studies, 2(6), 83-91.

Agustini, F. (2011). Manajemen sumber daya manusia lanjutan. Medan: Madenatera.

Andriani, S., Kesumawati, N., \& Kristiawan, M. (2018). The influence of the transformational leadership and work motivation on teachers performance. Internatioanl Journal of Scientific \& Technology Research, 7(7), 19-29.

Anuar, S. (2017). Pengaruh kepmimpinan dan motivasi terhadap kinerja karyawan melalui variabel intervening semangat kerja pada Bank Pundi Provinsi Riau. Jurnal Eko dan Bisnis (Riau Economic and Business Reviewe, 8(4), 32-45.

Bafadal, I. (2016). Penguatan manajemen pendidikan persekolahan dalam rangka menghasilkan sumber daya manusia di era kompetensi global. Seminar Nasional Penguatan Manajemen Pendidikan Era Kompetensi, 12 
Maret 2016 (pp. 513-526). Malang: Universitas Negeri Malang.

Damai, S., Effendi, R., \& Sulaiman. (2019). The teacher achievement motivation as an intervening variable in realtionship between teachers profesionalism, principals leadership and teachers perforamnce of state high school in Banjarmasin city. Journal of K6, Education and Management, 2(1), 23-35.

Dewi, K. (2016). Pengaruh motivasi dan gaya kepemimpinan terhadap kinerja karyawan melalui kepuasan kerja karyawan sebagai variabel intervening di PD BPR BKK Wonosobo. Jurnal Riset Manajemen, 3(1), 61-77.

Fatimah, S. (2015). Pengaruh stres kerja dan komitmen organisasi terhadap semangat kerja karyawan PT. BPR Indomitra Mega Kapital Pekanbaru. Jurnal Online Mahasiswa FEKON, 2(2), 1-15.

Hasibuan, M. P. (2013). Manajemen sumber daya manusia. Jakarta: Bumi Aksara.

Hasim, D. (2019). Pengaruh kepemimpinan, motivasi dan iklim kerja terhadap kinerja pegawai pada Dinas Kesejahteraan Sosial Kabupaten Biak Numfor. Pasuruan: Qiara Media.

Luthans, F. (2006). Perilaku organisasi. Yogyakarta: Andi.

Mulyasa, E. (2001). Menjadi kepala sekolah profesional. Bandung: Remaja Rosdakarya.

Noor, S., Wahyu, \& Suhaimi. (2019). Relationship principal leadership to work motivation, morale teacher and teacher performance of state junior high schools. Journal of $\mathrm{K6}$, Education, and Management, 2(1), 15-22.

Nurhaidah, M. M. (2015). Dampak pengaruh globalisasi bagi kehidupan. Jurnal Pesona Dasar, 3(3), 1-14.

Pradnyana, I. G., Mahanavami, G. A., \& Widari, N. L. (2016) Dampak gaya kepemimpinan dan semangat kerja terhadap kinerja karyawan pada PT. Bali Ocean Magic (Waterbom Bali) di Kuta, Badung. Jurnal Bisnis dan Kewirausahaan, 12(1), 42-52.

Priansa, D. J., \& Karwati, E. (2017). Kinerja dan profesionalisme kepala sekolah. Bandung: Alfabeta.

Putri, N. M. (3 September 2018). Pengaruh lingkungan kerja terhadap kinerja pegawai dengan semangat kerja sebagai variabel intervening pada Dinas Kesehatan Kabupaten Tabanan Bali. Seminar Nasional Royal (SENAR) 2018 (pp.
667-672). Kisaran, Asahan, Sumatera Utara: STMIK RoyalAMIK Royal.

Rumapea, P. (2005). Hubungan kewenangan kepala sekolah dengan kinerja guru. Jurnal Ilmu Pendidikan, 12(1), 1-11. doi:http://dx.doi.org/10.17977/jip.v12i1.80

Sari, D. P. (2016). Hubungan iklim sekolah dengan semangat kerja guru smk swasta se-kota Padang Panjang. Jurnal Administrasi Pendidikan, 1(4), 1-8. doi:10.23036/bmp.v4i1.5963

Soekarso, \& Putong, I. (2015). Kepemimpinan kajian teoritis dan praktis (Vol. 1). Jakarta: Erlangga.

Sukamto, Y., \& Pardjono. (2016). Pengaruh kompetensi guru, komitmen kerja dan motivasi kerja terhadap kinerja guru SMP Andalan di Sleman. Jurnal Penelitian Ilmu Pendidikan, 9(2), 167-178

Sumantri, B. (2017). Pengaruh kemampuan, motivasi dan semangat kerja terhadap kinerja guru SMP Negeri di Balongpanggang. Jurnal Mitra Pendidikan, 1(7), 789-800.

Suriansyah, A. (2014). Hubungan budaya sekolah, komunikasi, dan komitmen kerja. Jurnal Cakrawala Pendidikan, 358367.

Susanti, E., Erpidawati, \& Haskar, E. (2018). Pengaruh komitmen kerja dan disiplin kerja terhadap kerja terhadap semangat kerja dosen UMSB. Jurnal Menara Ilmu, 12(10), 58-64.

Tarlis, A. (2017). Pengaruh gaya kepemimpinan terhadap semangat kerja karyawan pada Bank Mandiri cabang Langsa. Jurnal Investasi Islam, 2(2), 1-20.

Tempel, A. D. (1987). Kepemimpinan. Jakarta: Gramedia.

Wahyuni, D. U., Christiananta, B., \& Eliyana, A. (2014). Influence of Organizational Commitment, Transactional Leadership, and Servant Leadership to the Work Motivation, Work Satisfaction and Work Performance of Teachers at Private Senior High Schools in Surabaya. Journal Educational Research International, 3(2), 82-96.

Werang, B. R., Irianto, O., \& Asmaningrum, H. P. (2019). Pengaruh motivasi dan semangat kerja terhadap kinerja guru SD di Distrik Mindiptana, Papua. (MUSAMUS, Ed.) Journal of Primary Education, 1(2), 93-103. doi:10.35724/musjpe.v1i2.1467

Yusuf, R. M., \& Syarif, D. (2018). Komitmen organisasi: definisi, dipengaruhi dan mempengaruhi. Makassar: Nas Media Pustaka. 